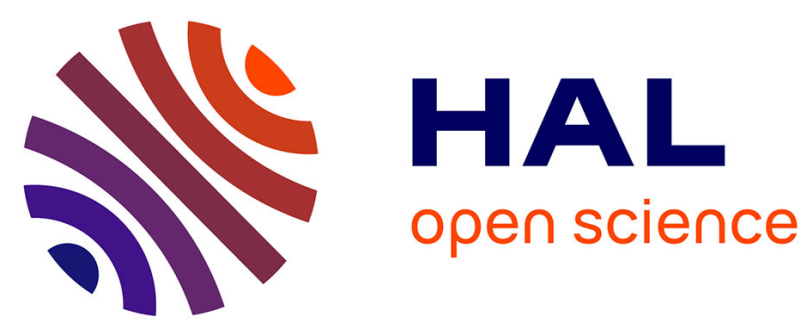

\title{
Development and validation of an optimized finite element model of the human orbit
}

\author{
Jean-Marc Foletti, Valentine Martinez, Nicolas Graillon, Yves
}

Godio-Raboutet, Lionel Thollon, Laurent Guyot

\section{- To cite this version:}

Jean-Marc Foletti, Valentine Martinez, Nicolas Graillon, Yves Godio-Raboutet, Lionel Thollon, et al.. Development and validation of an optimized finite element model of the human orbit. Journal of Stomatology, Oral and Maxillofacial Surgery, 2019, 120 (1), pp16-20. hal-02562666

\section{HAL Id: hal-02562666 \\ https://hal-amu.archives-ouvertes.fr/hal-02562666}

Submitted on 5 Jul 2021

HAL is a multi-disciplinary open access archive for the deposit and dissemination of scientific research documents, whether they are published or not. The documents may come from teaching and research institutions in France or abroad, or from public or private research centers.
L'archive ouverte pluridisciplinaire HAL, est destinée au dépôt et à la diffusion de documents scientifiques de niveau recherche, publiés ou non, émanant des établissements d'enseignement et de recherche français ou étrangers, des laboratoires publics ou privés. 
Version of Record: https://www.sciencedirect.com/science/article/pii/S2468785518301861

Manuscript_db33d4de743f2c817fcab864c148ff10

Development and validation of an optimized finite element model of the human orbit.

Foletti JM ${ }^{a}$, Martinez $V^{b}$, Graillon $N^{a}$, Godio-Raboutet $Y^{b}$, Thollon $L^{b}$, Guyot $L^{c}$

${ }^{a}$ Aix Marseille Univ, APHM, IFSTTAR, LBA, hôpital de la conception, service de chirurgie maxillofaciale, Marseille, France

${ }^{\mathrm{b}}$ Aix Marseille Univ, IFSTTAR, LBA, Marseille, France

'Aix Marseille Univ, APHM, CNRS, EFS, hôpital de la conception, service de chirurgie maxillo-faciale, Marseille, France

Jean Marc Foletti MD, MSc (corresponding author)

Maxillofacial senior lecturer, PhD student

Mail: jean-marc.foletti@ap-hm.fr

Tel: $+33(0) 619390984$

Address: Aix Marseille Univ, IFSTTAR, LBA UMR_T24, Faculté de Médecine - Secteur Nord, Boulevard Pierre Dramard, 13916, Marseille Cedex 20, France.

Valentine Martinez MSc

Medical student

Mail: valentine.martinez4@gmail.com

Nicolas Graillon MD, MSc

Fellow surgeon, PhD student

Mail: nicolas.graillon@ap-hm.fr

Yves Godio-Raboutet MSc

Research engineer

Mail: yves.godio@ifsttar.fr

Lionel Thollon MD, PhD

Biomechanics senior lecturer

Mail: lionel.thollon@ifsttar.fr

Laurent Guyot MD, PhD

Maxillofacial professor

Mail: Laurent.guyot@ap-hm.fr 
Abstract

Introduction: The authors' main purpose was to develop a detailed finite element model (FEM) of the human orbit and to validate it by analyzing its behavior under the stress of blunt traumas.

Materials and methods: A pre-existing 3D FEM of a human head was modified and used in this study. Modifications took into account preliminary research carried out on PubMed database. Data from a CT scan of the head were computed with Mimics ${ }^{\circledast}$ software to re-create the skull geometry. The mesh production, the model's properties and the simulations of blunt orbital traumas were conducted on Hyperworks ${ }^{\circledR}$ software.

Results: The resulting 3D FEM was composed of 640000 elements and was used to perform blunt trauma simulations on an intact orbit. A total of 27 tests were simulated. 15 tests were realized with a metallic cylinder impactor; 12 tests simulated a hit by a closed fist. In all the tests conducted (27/27), the orbital floor was fractured. Fracture patterns were similar to those found in real clinical situations according to the buckling and hydraulic theories of orbital floor fractures.

Discussion: The similitude between the fracture patterns produced on the model and those observed in vivo allows for a validation of the model. This model constitutes, at the authors knowledge, the most sophisticated one ever developed. .

Keywords: finite element analysis; maxillofacial; trauma; orbit; biomechanics 
Introduction

Fractures of the orbital floor and / or the medial wall of the orbit are common in maxillofacial traumas. Functional recovery requires precise anatomical reconstruction of the orbit and volume restoration. Open reduction with internal fixation tends to become the gold standard. Studying the behavior of these fractures may help to minimize iatrogenic morbidity. The use of a numerical model of the orbit that may be submitted to a wide range of traumas and reconstructions is of special interest because experiments can be carried out quickly and with no limitations regarding repetitions. Advances in software and computational capabilities have nowadays allowed for the development of very realistic finite element models (FEM).

Our main purpose was to develop a detailed FEM of the human orbit; our secondary objective was to analyze its behavior under the stress of different kinds of blunt traumas, so as to validate its reliability. 
Materials and methods

1 -Model description

A 3D FEM of a human head, which had previously been developed and validated by our team to study impacts on the mandible [1], was used as a basis and modified at the level of the orbits. dicom data from a $1 \mathrm{~mm}$-slice thickness CT scan of the head were computed with MICMICS $12.3^{\circledR}$ software (Materialise ${ }^{\circledR}$, Louvain, Belgium) to re-create the skull's geometry. The meshing was then produced using Hypermesh ${ }^{\circledast}$ software (Altair Engineering, Inc., Detroit, MI, USA). The model's properties were achieved with Radioss ${ }^{\circledR}$ (Altair Engineering, Inc., Detroit, MI, USA). The average element size was fixed at $3 \mathrm{~mm}$; the orbital floor and the medial orbital wall were meshed with $1.5 \mathrm{~mm}$ shell elements using three nodes. The skull was composed of three layers in order to distinguish the trabecular and cortical bones. The cortical bone mesh used shell elements with three nodes; the trabecular bone used tetrahedral elements. The facial bones were modeled separately to specify their measurements and the cortical bone's thickness. The subarachnoid space, the cerebrospinal fluid and the brain were added during the meshing process, using tetrahedral elements. To make our FEM lighter, the scalp and the mandible have been neglected. All mechanical properties were taken from literature data [18].

\section{2 -Blunt trauma simulations}

Numerous simulations of blunt traumas of the orbit were run on Hypercrash12.0 ${ }^{\circledR}$ (Altair Engineering, Inc., Detroit, MI, USA) first by using a FEM of a metallic cylinder impactor ( $m=300-400 \mathrm{~g}$ ) 
and then a FEM of a closed fist, reproducing a straight punch [9]. Both of these impactors were computed in order to hit the inferior rim of the orbit (acceleration $=6-7 \mathrm{~m} . \mathrm{s}^{-1}$ )

The tests were conducted with several variations of the FEM. For each test, the weight and acceleration of the impactors were modulated. The impacts successively affected an empty orbit, and then an orbit filled with fat and an eyeball. Most of the impacts were located on the inferior orbital rim. For 3 of the tests conducted with the metallic cylinder, the impact point was located on the eyeball. A preliminary series of tests had been performed to correct the failures of the FEM and to determine precisely the best impact points. These tests are not reported here. In total27 tests were simulated and included in our study. Their characteristics are summarized in table 1

Results

1 -Model description (figure 1)

Our FEM of the head and orbit consisted of around 600000 volumetric elements (tetrahedral and brick elements) and 40000 shell elements (from 3 to 4 nodes).

\section{2 - Blunt trauma simulations}

A total of 27 tests were simulated. 15 tests were realized with a metallic cylinder impactor; 12 tests simulated a hit by a closed fist (figure 2).

In all the tests conducted (27/27), the orbital floor fractured. In 77,8\% (21/27) an additional fracture of the zygomatic bone was associated. Moreover, in $74 \%(20 / 27)$ the anterior wall of the maxillary 
sinus was fractured. An associated fracture of the lamina papyracea was encountered in $22,3 \%$ $(6 / 27)$ of the tests.

Finally our series of hits distinguished two major scenarios: Bone impacts resulted in anterior fractures of the orbital floor, with associated fractures of the inferior orbital rim and the anterior wall of the maxillary sinus (figure 3). Impacts located on the eyeball induced isolated fractures of the orbital floor and fractures of the area located between the orbital floor and the medial wall (lamina papyracea). Characteristics of the hits performed are summarized in table 1.

Discussion

We designed a FEM of the human orbit optimized to be as realistic as possible and consistent with current literature data. Furthermore, our FEM underwent a series of blunt traumas reproducing realistic fractures of the floor of the orbit, which we consider sufficient to validate our model.

Additions to Tuchtan's model [1] took into account the results found by Weaver et al [10] regarding the dimensions and the positioning of the eyeball, and those achieved by Karimi et al [11] as for the properties of intra- and extraconal fat.

In 2006, Al-Sukhun et al $[12,13]$ emphasized the advantages of finite element analysis in order to study the phenomenon of orbital deformation but insisted on the oversimplification of the FEM models available at that time. First they devised a model including the eyeball and the bony orbit, taking into account the oculomotor muscles' movements, and based on an experimental 
determination of the mechanical properties and the different components. The validation of their model was based on the comparison between the orbital floor and medial wall fracture patterns and those observed in clinical practice. However, Al-Sukhun's FEM design was limited by computational capabilities and was characterized by a low degree of precision (only 6400 brick elements). In 2012, Schaller et al [16] designed a precise model of the skull including the orbit, consisting of 736,934 elements, highlighting the gain in precision allowed in trauma simulations. Their model also allowed for the attribution of different mechanical properties to the anatomical structures. The authors pointed out the absence of soft tissues as the main limit of their model. In 2013 , Schaller added to his pure bony orbital model a schematic eyeball and periorbital soft tissues, including intraorbital fat and oculomotor muscles [18]. Using the same model, Rossi et al [20] and Esposito et al [21] focused on 3D geometry of the orbit in case of blast traumas. They concluded that the pyramid-like shape of the orbit as well as the interface between fluid content and anterior air-tissue interface result in a pressure wave reflection and amplification, accounting for macular and optic nerve damage in case of ocular blast injury.

Our model is meant to achieve the sum of these successive improvements. We have avoided oversimplification and achieved a precise anatomical 3D modeling of the human skull. We have distinguished between the cortical and cancellous bones and taken into account the average bone thickness of each area. . Special attention has been paid to the meshing of the most fragile parts, the orbital floor and the medial wall. 17 of the tests were performed after an improvement of these areas consisting into meshing in smaller elements. This allowed for more realistic fracture simulations. 
Soft tissues have also been gradually included in our FEM. Schutte made a distinction between intraand extraconal fat [23], which demonstrated that the supporting action of the orbital fat plays an important role in the suspension of the eye in the orbit and in the stabilization of rectus muscle paths. Likewise, Schoemaker [24] established that although the stiffness of orbital fat is low, its support is crucial to stabilize the oculomotor muscles. Our results gained in precision with the filled orbit simulations compare to the empty orbit tests.

All fracture patterns resulting from our simulations occur regularly in trauma patients. We considered this good correlation between our numerical results and real clinical situations as an argument in favor of the validity of our model. However, an anatomic validation of our model should be planned.

The series of hits with a metallic impactor allowed for studying different points of impact: Bone impacts resulted in anterior fractures of the orbital floor associated with orbital rim fractures (figure 3), whereas impacts located on the eyeball induced isolated fractures of the orbital floor and of the medial wall (cf supra). These findings were consistent with the buckling versus hydraulic theory [25] of orbital floor blowout fractures. In all cases, the kinetic energy developed in our experimentations $(5,4$ to $12,25 \mathrm{~J})$ was significantly higher than the average energy theoretically required to induce orbital floor fractures (1,2 to $1,5 \mathrm{~J})$ [25] (figure 4).

The series of hits with a closed fist was performed to add even more realism to our model. Compare to the metallic cylinder, the hit by a closed fist was distributed over the entire anterior orbital rim. Mass and speed of the fist were modulated to reproduce an average direct punch to the face [9]. 
According to Schaller et al [18], the use of a transient dynamic simulation was considered as a much more realistic loading scenario than a static analysis with calculated impact forces to simulate the hit of the orbital rim by a closed fist.

The absence of detailed anatomy of the ethmoid is a limit of our model. Ramesh et al [26] proved that ethmoidectomy on post mortem human subject reduces the impact energy necessary to induce orbital fractures and increases the prevalence of the medial wall's involvement.

We favored traumas targeting the inferior orbital rim, and then obtained fractures consistent with the buckling theory of orbital fractures, with an anterior location, frequently associated fractures of the inferior orbital rim, and without any extension to the medial wall of the orbit (figure 3).

The contribution of anatomical experiments to the validation of numerical experiments has already proved its value both in traumatology and in general surgery FEM [27-29]. The reliability of our model could be further improved and validated by the completion of a study on anatomical subjects.

Finally, FEM has proved to be a valuable tool to determine the most adapted way to repair fractures [13; 19]. Further studies using our model are planned to assess the behavior of titanium mesh implants (TMIs) used for orbital floor reconstruction. TMIs provide a reliable support for the orbital contents but their relative stiffness may also become a potential disadvantage in case of recurrent injuries as the implant may become distorted and behave as a penetrating foreign body able to threaten the intra-orbital content (eyeball, nerves vessels) [30]. Finite element analysis could confirm this potential threat, and help to improve the design of TMIs. 


\section{Bibliography}

1. Tuchtan L, Piercecchi-Marti MD, Bartoli C, Boisclair D, Adalian P, Léonetti G, Behr M, Thollon L. Forces transmission to the skull in case of mandibular impact. Forensic Sci Int. 2015;252:22-8

2. Armentani E, Caputo F, Citarella R. FEM sensitivity analyses on the stress levels in a human mandible with a varying ATM modelling complexity. Open MechEng J 2010;4:8-15

3. Versluis A, Tantbirojn D, Pintado MR, DeLong R, Douglas WH. Residual shrinkage stress distributions in molars after composite restoration. Dent Mater 2004;20:554-564

4. Wang RZ, Weiner S. Strain-structure relations in human teeth using Moiré fringes. J. Biomech 1998;31:135-141

5. Willinger R, Kang HS, Diaw B. Three-dimensional human head finite-element model validation against two experimental impacts. Ann Biomed Eng. 1999;27:403-410

6. Wong RCW, Tideman H, Merkx MAW, Jansen J, Goh SM, Liao K. Review of biomechanical models used in studying the biomechanics of reconstructed mandibles Int J Oral Maxillofac Surg;40:393-400

7. Joseph D, Gu WY, Mao XG, Lai WM, Mow VC. True density of normal and enzymatically treated bovine articular cartilage. Trans Orthop Res Soc 1999;24:642

8. Raul JS, Deck C, Willinger R, Ludes B. Finite-element models of the human head and their applications in forensic practice. Int J Legal Med 2008;122:359-366

9. Whiting WC, Gregor RJ, Finerman GA. Kinematic analysis of human upper extremity movements in boxing. Am J Sports Med. 1988;16:130-136 
10. Weaver AA, Loftis KL, Duma SM, Stitzel JD. Biomechanical modeling of eye trauma for different orbit anthropometries.JBiomech. 2011 29;44:1296-1303

11. Karimi A, Razaghi R, Navidbakhsh M, Sera T, Kudo S. Computing the stresses and deformations of the human eye components due to a high explosive detonation using fluid-structure interaction model. Injury. 2016;47:1042-1050

12. Al-Sukhun J, Kontio R, Lindqvist C. Orbital stress analysis--Part I: Simulation of orbital deformation following blunt injury by finite element analysis method. J Oral Maxillofac Surg. 2006;64:434-442

13. Al-Sukhun J, Lindqvist C, Kontio R. Modelling of orbital deformation using finite-element analysis. J R Soc Interface. 2006 22;3:255-262

14. Al-Sukhun J, Penttilä H, Ashammakhi N. Orbital stress analysis: part III: biomechanics of orbital blowout fracture repair using bioresorbable poly-L/DL-lactide (P[L/DL]LA 70:30) implant. J Craniofac Surg. 2011;22:1299-1303

15. Al-Sukhun J, Penttilä H, Ashammakhi N. Orbital stress analysis: part II: design and fixation of autogenous bone graft used to repair orbital blowout fracture. J Craniofac Surg. 2011;22:1294-1298 16. Schaller A, Voigt C, Huempfner-Hierl H, Hemprich A, Hierl T. Transient finite element analysis of a traumatic fracture of the zygomatic bone caused by a head collision. Int J Oral Maxillofac Surg. 2012;41:66-73

17. Al-Sukhun J, Penttilä H, Ashammakhi N. Orbital stress analysis, Part IV: Use of a "stiffnessgraded" biodegradable implants to repair orbital blow-out fracture. J Craniofac Surg. 2012;23:126130 
18. Schaller A, Huempfner-Hierl H, Hemprich A, Hierl T. Biomechanical mechanisms of orbital wall fractures - a transient finite element analysis. J Craniomaxillofac Surg. 2013;41:710-717

19. Al-sukhun J, Penttilä H, Ashammakhi N. Orbital stress analysis, part V: systematic approach to validate a finite element model of a human orbit. J Craniofac Surg. 2012;23:669-674

20. Rossi T, Boccassini B, Esposito L, Clemente C, lossa M, Placentino L, Bonora N. Primary blast injury to the eye and orbit: finite element modeling. Invest Ophthalmol Vis Sci. 2012;53:8057-8066.

21. Esposito L, Clemente C, Bonora N, Rossi T. Modelling human eye under blast loading. Comput Methods Biomech Biomed Engin. 2015;18:107-115.

22. Bhardwaj R, Ziegler K, Seo JH, Ramesh KT, Nguyen TD. A computational model of blast loading on the human eye.Biomech Model Mechanobiol. 2014;13:123-140

23. Schutte S, van den Bedem SP, van Keulen F, van der Helm FC, Simonsz HJ. A finite-element analysis model of orbital biomechanics. Vision Res. 2006;46:1724-1731.

24. Schoemaker I, Hoefnagel PP, Mastenbroek TJ, Kolff CF, Schutte S, van der Helm FC, Picken SJ, Gerritsen AF, Wielopolski PA, Spekreijse H, Simonsz HJ. Elasticity, viscosity, and deformation of orbital fat. Invest Ophthalmol Vis Sci. 2006;47:4819-4826

25. Ahmad F, Kirkpatrick NA, Lyne J, Urdang M, Waterhouse N. Buckling and hydraulic mechanisms in orbital blowout fractures: fact or fiction? J Craniofac Surg. 2006;17:438-441

26. Ramesh S, Bokman C, Mustak H, Lo C, Goldberg R, Rootman D. Medial Buttressing in Orbital Blowout Fractures. Ophthalmic PlastReconstr Surg. 2018

27. Bège T, Ménard J, Tremblay J, Denis R, Arnoux PJ, Petit Y. Biomechanical analysis of traumatic mesenteric avulsion. Med BiolEngComput. 2015;53:187-194. 
28. Behr M, Arnoux PJ, Serre T, Bidal S, Kang HS, Thollon L, Cavallero C, Kayvantash K, Brunet C. A human model for road safety: from geometrical acquisition to model validation with radioss. Comput Methods Biomech Biomed Engin. 2003;6:263-273.

29. Arnoux PJ, Cesari D, Behr M, Thollon L, Brunet C. Pedestrian lower limb injury criteria evaluation: a finite element approach. Traffic Inj Prev. 2005;6:288-297.

30. Foletti JM, Scolozzi P. Severe distortion of an orbital titanium mesh implant after recurrent facial trauma: a potential threat to the orbital contents? Br J Oral Maxillofac Surg. 2017;55:836-838 
Figure captions

Figure 1 - Finite element model of the human head and orbit; The right orbit is empty, the left one is filled with fat and eyeball.

Figure 2 - Different impactors were used in our study: The simplified boxing glove previously described by Tuchtan et al [1] proved to be too large, and unsuited for our needs (A). We successively performed impacts with a metallic cylinder (B) and with a closed fist FEM (C), varying the weight and acceleration of these impactors for each test.

Figure 3 - Left inferior orbital rim shock with a $300 \mathrm{~g}$ metallic cylinder impactor at $7 \mathrm{~m} / \mathrm{s}(\mathrm{A})$, resulting in an anterior fracture of the orbital floor, associated with zygomatic bone fracture at the impact point (B). For clarity, the eyeball and the intraorbital fat are not represented here.

Figure 4 - Von Mises stress distribution after a $7 \mathrm{~m} / \mathrm{s}$ impact located on the left inferior orbital rim with a 300g metallic cylinder impactor. Higher levels of stress distribution (red) result in bone failure. The fracture pattern obtained is concordant with the buckling theory of orbital floor fractures. 

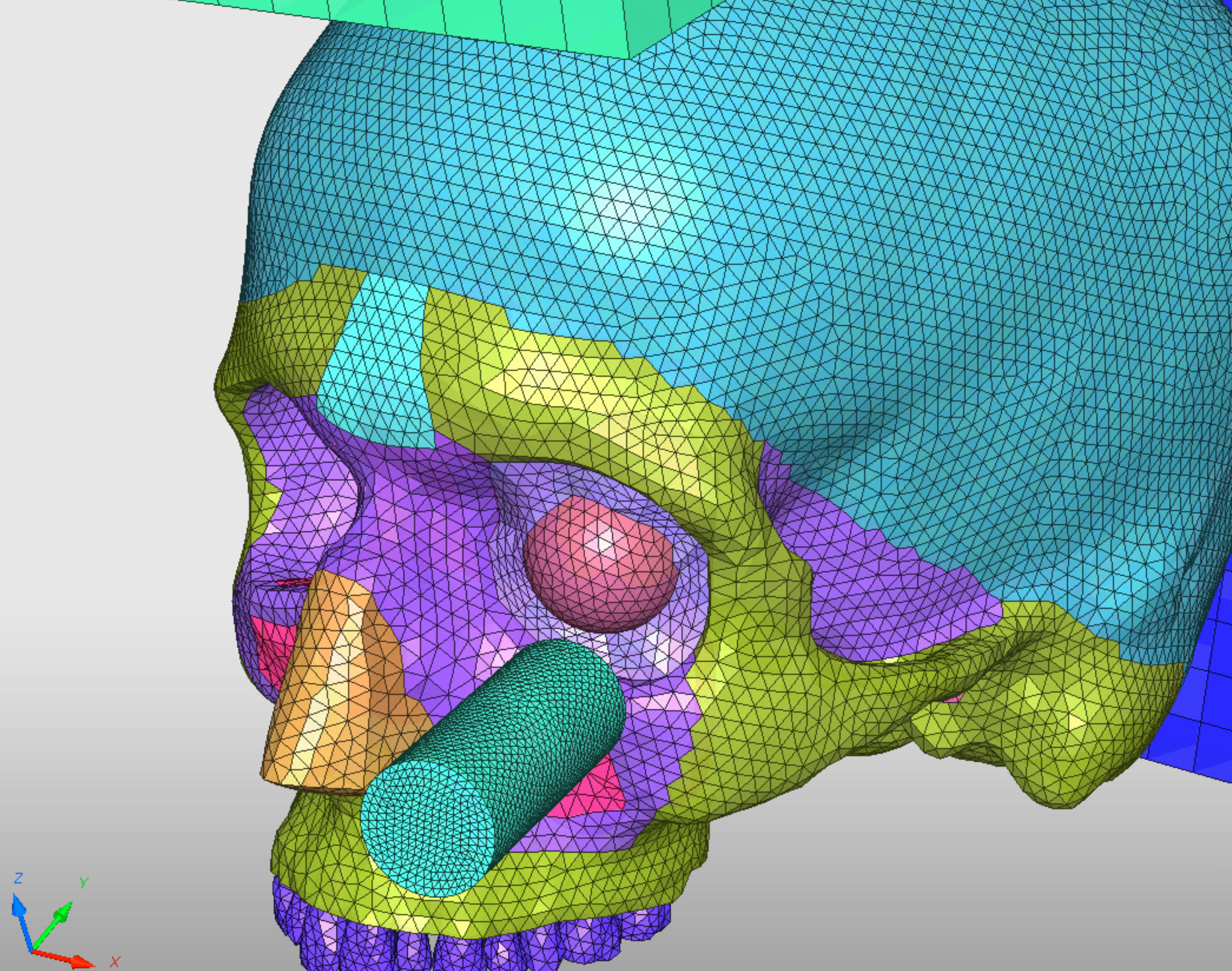

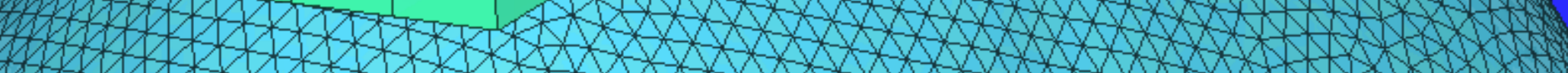

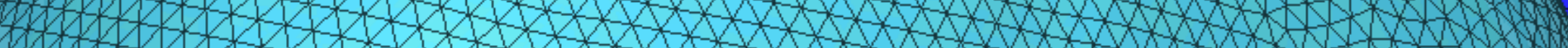

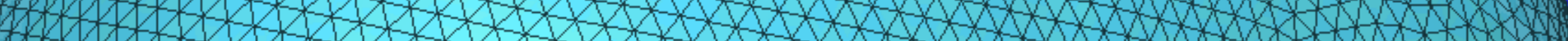

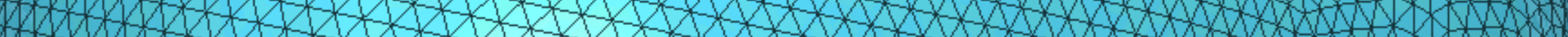

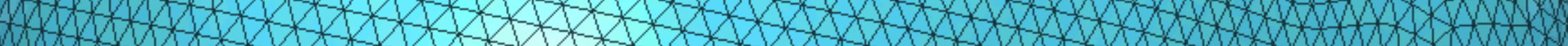

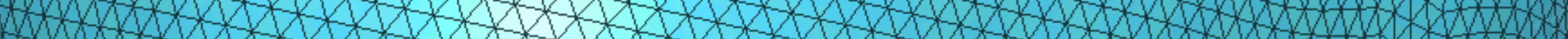

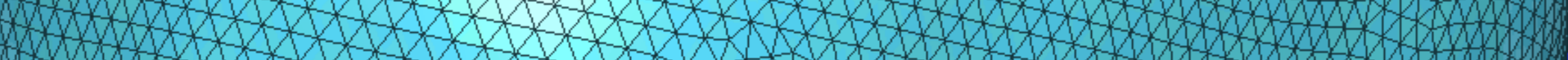

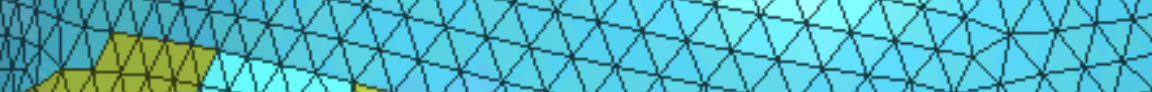

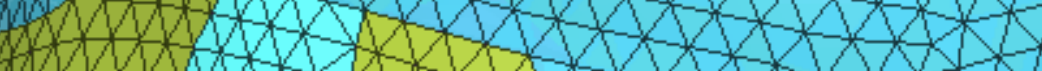

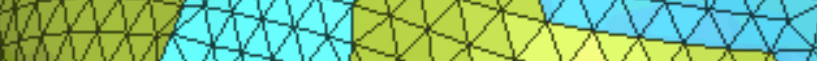

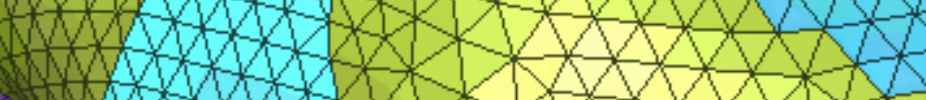

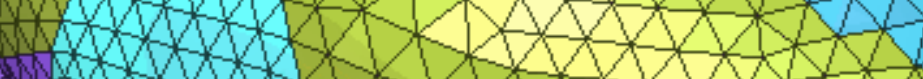

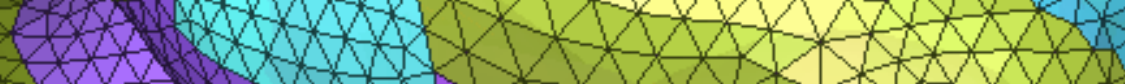

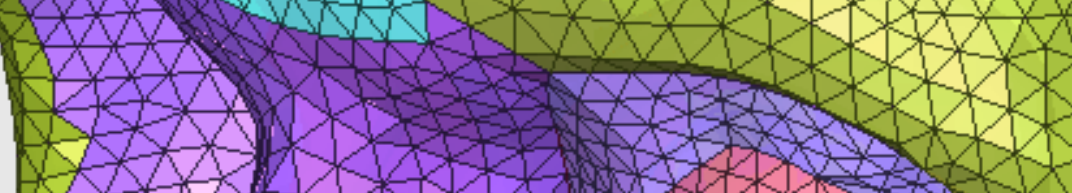

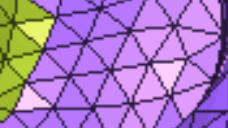

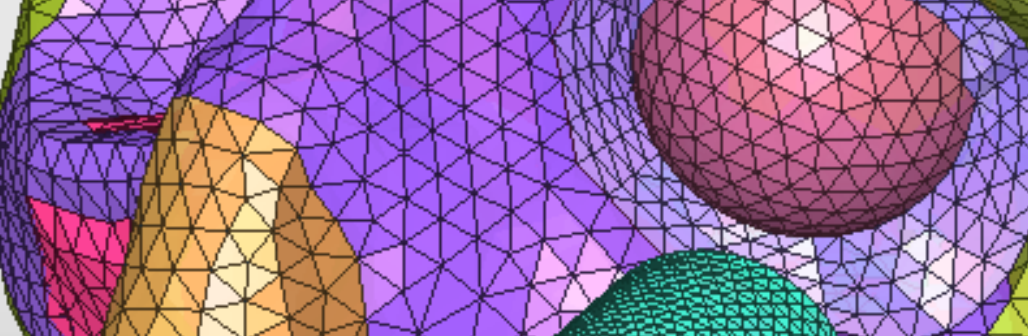

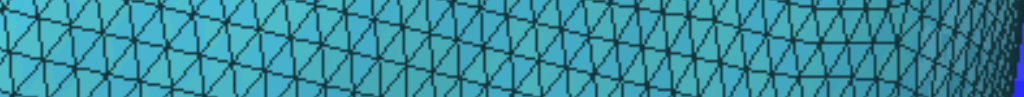

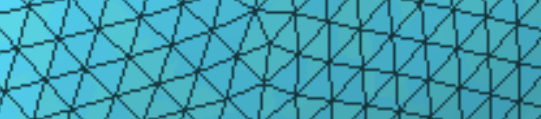

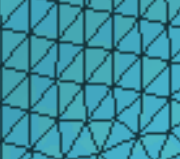

$+\infty 211$

St

$1-7+272501$ H

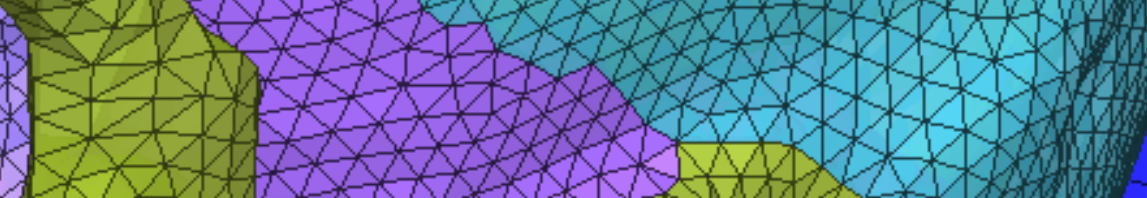
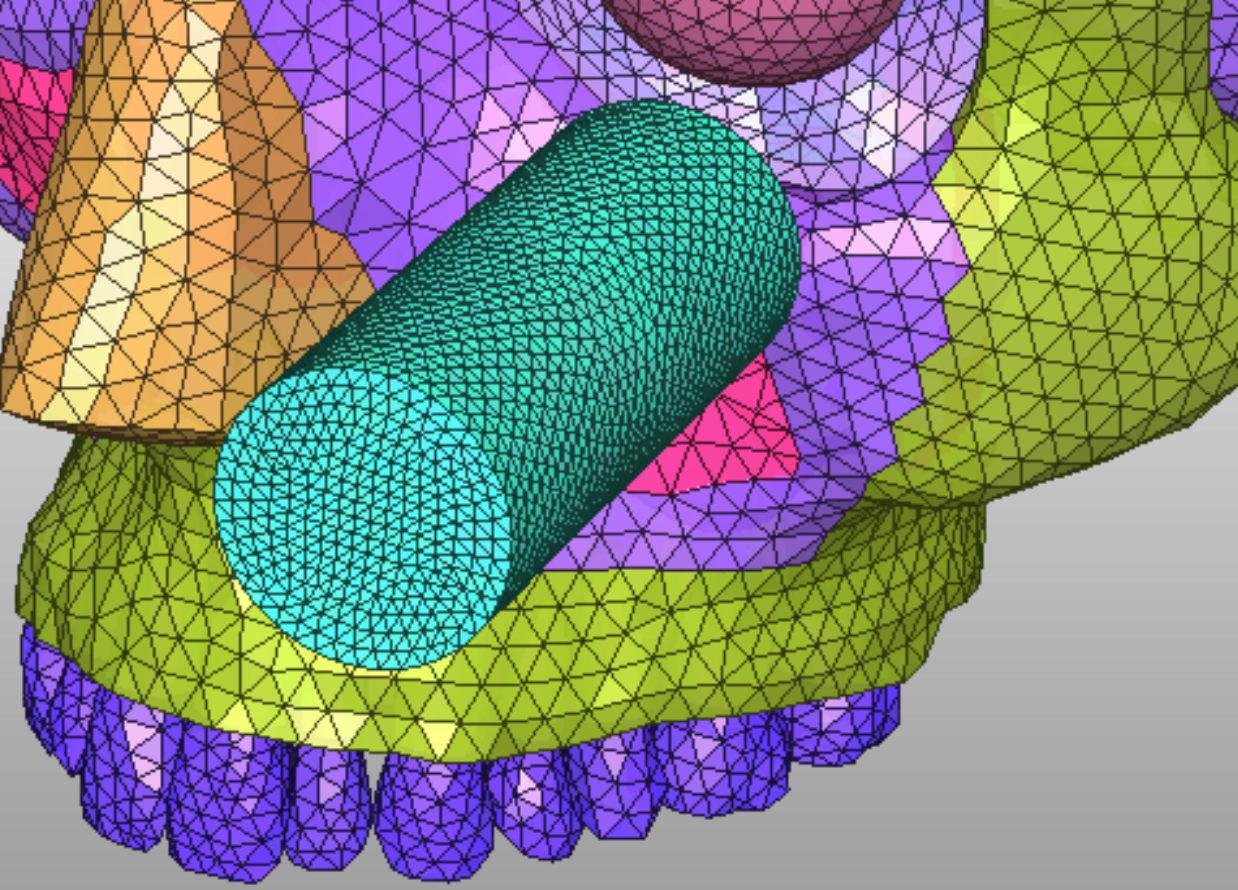

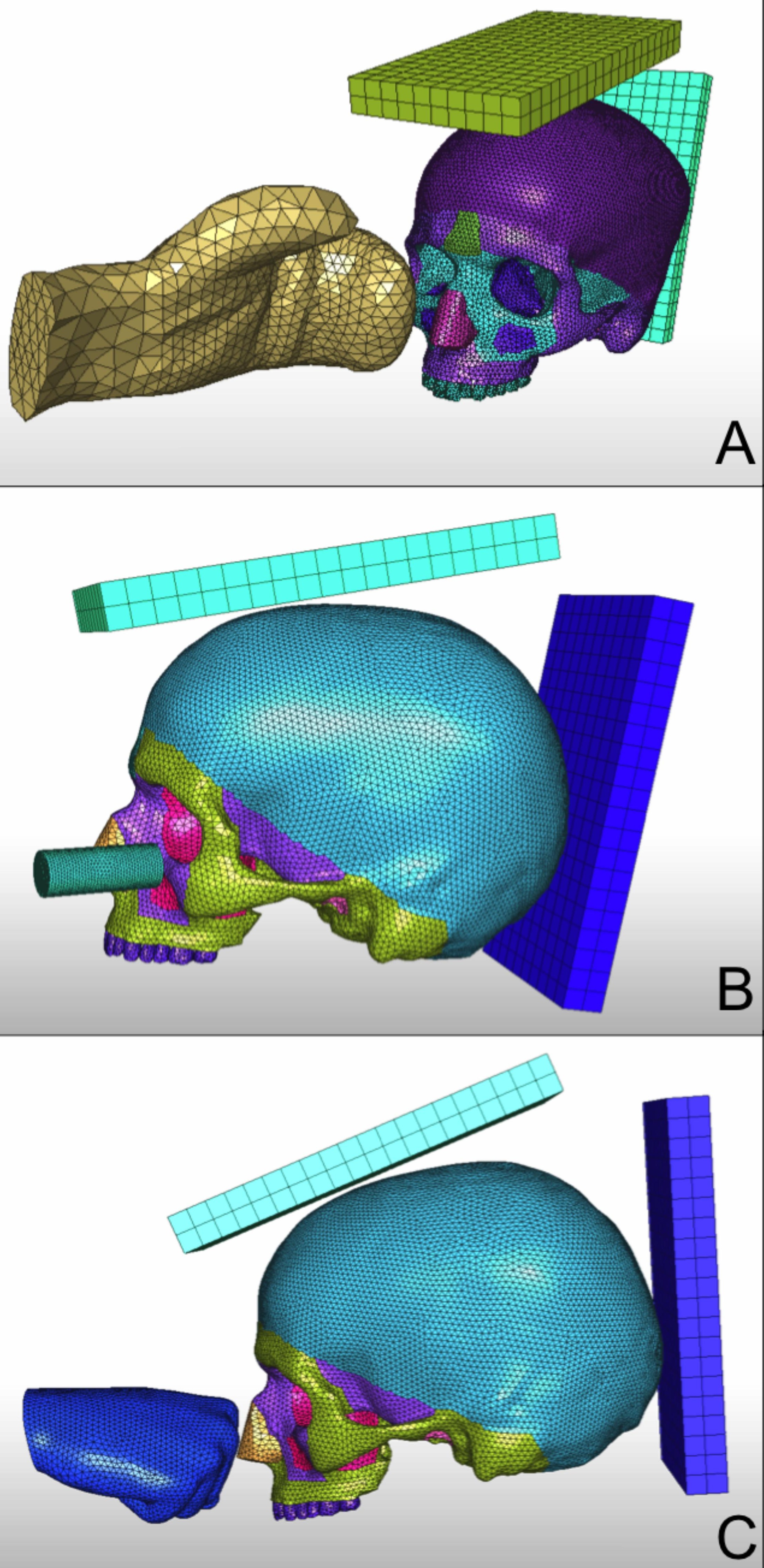
问 (n) 1 (1)

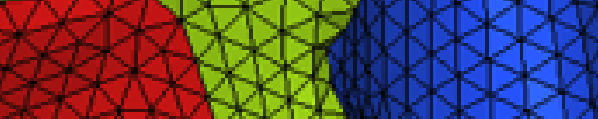
$7 \times 2+2$ $127-12$ $12+1$

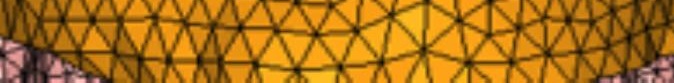

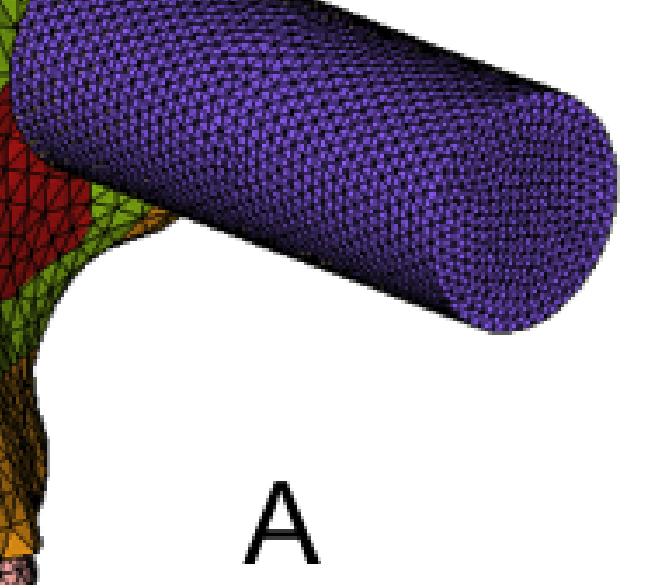

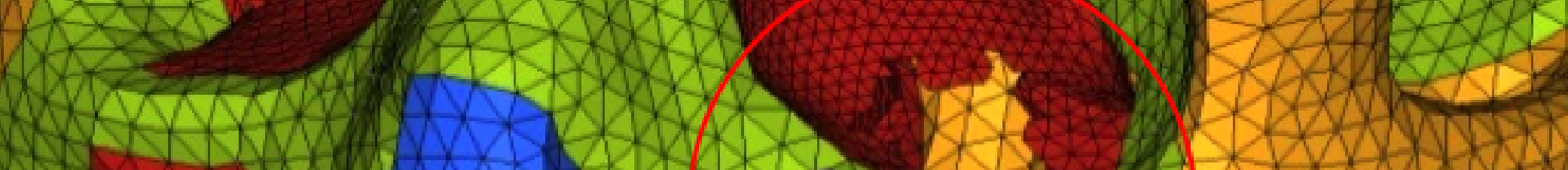
H.

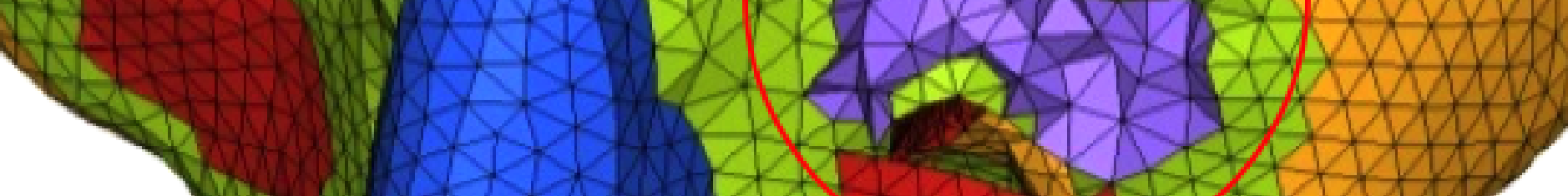

A 
No result
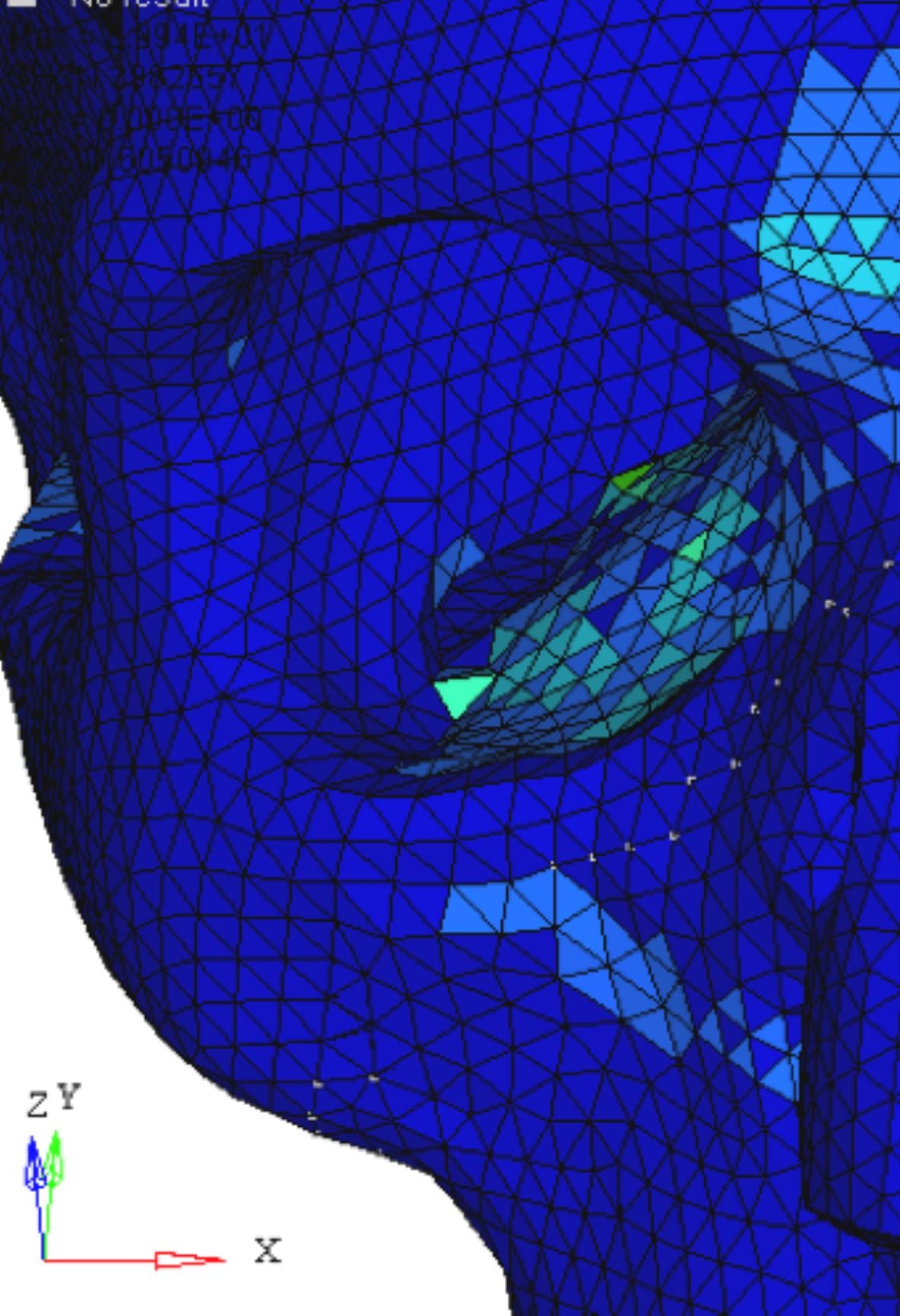


\begin{tabular}{|c|c|c|c|c|c|c|}
\hline test & $\begin{array}{c}\text { orbit } \\
\text { status }\end{array}$ & Orbital floor status & impactor & $\begin{array}{l}\text { acceleration } \\
(\mathrm{m} / \mathrm{s})\end{array}$ & $\begin{array}{l}\text { weight } \\
\text { (g) }\end{array}$ & results \\
\hline 1 & EO & intact & metallic cylinder & 6 & 300 & $\begin{array}{l}\text { anterior fracture of the orbital floor; zyogma is fractured at the inferior } \\
\text { orbital rim and the anterior wall of maxillary sinus }\end{array}$ \\
\hline 2 & EO & intact & metallic cylinder & 7 & 300 & $\begin{array}{l}\text { anterior fracture of the orbital floor; zyogma is fractured at the inferior } \\
\text { orbital rim and the anterior wall of maxillary sinus }\end{array}$ \\
\hline 3 & EO & intact & metallic cylinder & 6 & 400 & $\begin{array}{l}\text { anterior fracture of the orbital floor; zyogma is fractured at the inferior } \\
\text { orbital rim and the anterior wall of maxillary sinus }\end{array}$ \\
\hline 4 & EO & intact & metallic cylinder & 7 & 400 & $\begin{array}{l}\text { anterior fracture of the orbital floor; zyogma is fractured at the inferior } \\
\text { orbital rim and the anterior wall of maxillary sinus }\end{array}$ \\
\hline 5 & EO & intact & metallic cylinder & 6 & 500 & $\begin{array}{l}\text { important fracture of the orbital floor; zyogma is fractured at the inferior } \\
\text { orbital rim and the anterior wall of maxillary sinus }\end{array}$ \\
\hline 6 & EO & intact & metallic cylinder & 7 & 500 & $\begin{array}{l}\text { important fracture of the orbital floor; zyogma is fractured at the inferior } \\
\text { orbital rim and the anterior wall of maxillary sinus }\end{array}$ \\
\hline 7 & EO & $\begin{array}{l}\text { intact / meshing } \\
\text { detailed in smaller } \\
\text { elements }\end{array}$ & metallic cylinder & 6 & 300 & anterior fracture of the orbital floor \\
\hline 8 & EO & $\begin{array}{l}\text { intact / meshing } \\
\text { detailed in smaller } \\
\text { elements }\end{array}$ & metallic cylinder & 7 & 300 & anterior fracture of the orbital floor \\
\hline 9 & EO & $\begin{array}{l}\text { intact / meshing } \\
\text { detailed in smaller } \\
\text { elements }\end{array}$ & metallic cylinder & 6 & 400 & important fracture of the orbital floor \\
\hline 10 & EO & $\begin{array}{l}\text { intact / meshing } \\
\text { detailed in smaller } \\
\text { elements }\end{array}$ & metallic cylinder & 7 & 400 & $\begin{array}{l}\text { important fracture of the orbital floor; zyogma is fractured at the inferior } \\
\text { orbital rim and the anterior wall of maxillary sinus }\end{array}$ \\
\hline 11 & EO & $\begin{array}{l}\text { intact / meshing } \\
\text { detailed in smaller } \\
\text { elements }\end{array}$ & metallic cylinder & 6 & 500 & $\begin{array}{l}\text { important fracture of the orbital floor; zyogma is fractured at the inferior } \\
\text { orbital rim and the anterior wall of maxillary sinus; lamina papyracea is } \\
\text { fractured }\end{array}$ \\
\hline 12 & EO & $\begin{array}{l}\text { intact / meshing } \\
\text { detailed in smaller } \\
\text { elements }\end{array}$ & metallic cylinder & 7 & 500 & $\begin{array}{l}\text { important fracture of the orbital floor; zyogma is fractured at the inferior } \\
\text { orbital rim and the anterior wall of maxillary sinus }\end{array}$ \\
\hline 13 & $\begin{array}{l}\text { FO fat } \\
\text { eyeball }\end{array}$ & $\begin{array}{l}\text { intact / meshing } \\
\text { detailed in smaller } \\
\text { elements }\end{array}$ & $\begin{array}{l}\text { metallic cylinder / } \\
\text { impact on the } \\
\text { eyeball }\end{array}$ & 6 & 300 & $\begin{array}{l}\text { posterior and internal fracture of the orbital floor; lamina papyracea is } \\
\text { fractured }\end{array}$ \\
\hline 14 & $\begin{array}{l}\text { FO fat } \\
\text { eyeball }\end{array}$ & $\begin{array}{l}\text { intact / meshing } \\
\text { detailed in smaller } \\
\text { elements }\end{array}$ & $\begin{array}{l}\text { metallic cylinder / } \\
\text { impact on the } \\
\text { eyeball }\end{array}$ & 6 & 500 & important fracture of the orbital floor; lamina papyracea is fractured \\
\hline
\end{tabular}




\begin{tabular}{|c|c|c|c|c|c|c|}
\hline 15 & $\begin{array}{l}\text { FO fat } \\
\text { eyeball }\end{array}$ & $\begin{array}{l}\text { intact / meshing } \\
\text { detailed in smaller } \\
\text { elements }\end{array}$ & $\begin{array}{l}\text { metallic cylinder / } \\
\text { impact on the } \\
\text { eyeball }\end{array}$ & 7 & 300 & important fracture of the orbital floor; lamina papyracea is fractured \\
\hline 16 & EO & intact & closed fist & 7 & 1300 & $\begin{array}{l}\text { important orbito-zygomatic and maxilla fracture; lamina papyracea is } \\
\text { fractured }\end{array}$ \\
\hline 17 & EO & intact & closed fist & 6 & 1300 & important orbito-zygomatic and maxilla fracture \\
\hline 18 & EO & intact & closed fist & 7 & 800 & $\begin{array}{l}\text { important fracture of the orbital floor; zyogma is fractured at the inferior } \\
\text { orbital rim and the anterior wall of maxillary sinus }\end{array}$ \\
\hline 19 & EO & intact & closed fist & 6 & 800 & $\begin{array}{l}\text { anterior fracture of the orbital floor; zyogma is fractured at the inferior } \\
\text { orbital rim and the anterior wall of maxillary sinus }\end{array}$ \\
\hline 20 & EO & $\begin{array}{l}\text { intact / meshing } \\
\text { detailed in smaller } \\
\text { elements }\end{array}$ & closed fist & 7 & 800 & $\begin{array}{l}\text { anterior fracture of the orbital floor; zyogma is fractured at the inferior } \\
\text { orbital rim and the anterior wall of maxillary sinus }\end{array}$ \\
\hline 21 & EO & $\begin{array}{l}\text { intact / meshing } \\
\text { detailed in smaller } \\
\text { elements }\end{array}$ & closed fist & 6 & 800 & $\begin{array}{l}\text { anterior fracture of the orbital floor; zyogma is fractured at the inferior } \\
\text { orbital rim and the anterior wall of maxillary sinus }\end{array}$ \\
\hline 22 & EO & $\begin{array}{l}\text { intact / meshing } \\
\text { detailed in smaller } \\
\text { elements }\end{array}$ & closed fist & 7 & 650 & $\begin{array}{l}\text { anterior fracture of the orbital floor; zyogma is fractured at the inferior } \\
\text { orbital rim and the anterior wall of maxillary sinus }\end{array}$ \\
\hline 23 & EO & $\begin{array}{l}\text { intact / meshing } \\
\text { detailed in smaller } \\
\text { elements }\end{array}$ & closed fist & 6 & 650 & $\begin{array}{l}\text { anterior fracture of the orbital floor; zyogma is fractured at the inferior } \\
\text { orbital rim and the anterior wall of maxillary sinus }\end{array}$ \\
\hline 24 & $\begin{array}{l}\text { FO fat } \\
\text { eyeball }\end{array}$ & $\begin{array}{l}\text { intact / meshing } \\
\text { detailed in smaller } \\
\text { elements }\end{array}$ & closed fist & 7 & 800 & $\begin{array}{l}\text { anterior fracture of the orbital floor; zyogma is fractured at the inferior } \\
\text { orbital rim and the anterior wall of maxillary sinus }\end{array}$ \\
\hline 25 & $\begin{array}{l}\text { FO fat } \\
\text { eyeball }\end{array}$ & $\begin{array}{l}\text { intact / meshing } \\
\text { detailed in smaller } \\
\text { elements }\end{array}$ & closed fist & 6 & 800 & $\begin{array}{l}\text { anterior fracture of the orbital floor; zyogma is fractured at the inferior } \\
\text { orbital rim and the anterior wall of maxillary sinus; lamina papyracea is } \\
\text { fractured }\end{array}$ \\
\hline 26 & $\begin{array}{l}\text { FO fat } \\
\text { eyeball }\end{array}$ & $\begin{array}{l}\text { intact / meshing } \\
\text { detailed in smaller } \\
\text { elements }\end{array}$ & closed fist & 7 & 650 & $\begin{array}{l}\text { anterior fracture of the orbital floor; zyogma is fractured at the inferior } \\
\text { orbital rim and the anterior wall of maxillary sinus }\end{array}$ \\
\hline 27 & $\begin{array}{l}\text { FO fat } \\
\text { eyeball }\end{array}$ & $\begin{array}{l}\text { intact / meshing } \\
\text { detailed in smaller } \\
\text { elements }\end{array}$ & closed fist & 6 & 650 & $\begin{array}{l}\text { anterior fracture of the orbital floor; zyogma is fractured at the inferior } \\
\text { orbital rim and the anterior wall of maxillary sinus }\end{array}$ \\
\hline
\end{tabular}

Table 1 - Summary of the characteristics and results of the 41 simulations of blunt trauma performed on a 3D finite element model of the human orbit. The orbit status (empty EO versus filled with fat and the eyeball FO), , the type of impactor, its speed and mass are precised for each of the 41 tests. 